\title{
Order! Order! Order in the House!
}

\section{DIAMAP: a road map for European diabetes research}

\author{
P. A. Halban • U. Smith
}

Published online: 12 August 2008

(C) Springer-Verlag 2008

Keywords Diabetes research · Europe $\cdot$ Research funding · Science policy

$\begin{array}{ll}\text { Abbreviations } \\ \text { DIAMAP } & \text { Road Map for Diabetes Research in Europe } \\ \text { EURADIA } & \text { Alliance for European Diabetes Research } \\ \text { NIDDK } & \begin{array}{l}\text { National Institute of Diabetes and Digestive } \\ \text { and Kidney Diseases }\end{array} \\ \text { NIH } & \text { National Institutes of Health }\end{array}$

\section{The need for coordination of European diabetes} research

Order! Order! Order in the House! So says the Speaker in Parliament at Westminster, more or less effectively. But European diabetes research has no speaker, no parliament, no voice. There is a lack of collective vision and coordination and unclear scientific rationale for public or private funding of European diabetes research. It is hardly surprising diabetes research in Europe is not as effective as it could be, despite its historical and continuing strength.

We both recognise the importance of national sovereignty and the right of each country to have its own research

P. A. Halban

EURADIA (Alliance for European Diabetes Research) and DIAMAP (Road Map for Diabetes Research in Europe),

Düsseldorf, Germany

U. Smith

EASD (European Association for the Study of Diabetes),

Düsseldorf, Germany

P. A. Halban $(\square)$

Department of Genetic Medicine and Development,

University of Geneva Medical Centre,

1 rue Michel-Servet,

1211 Geneva 4, Switzerland

e-mail: philippe.halban@medecine.unige.ch policy. We are both weary of centralised authority with its self-righteousness, numbing bureaucracy and cost-ineffectiveness. We agree with A. A. Milne (creator of Winnie-thePooh) who said: 'One of the advantages of being disorderly is that one is constantly making exciting discoveries.' Yet order and coordination in just the right dose can foster creativity, discovery and improved return on investment. Consider the situation in the USA. The National Institute of Diabetes and Digestive and Kidney Diseases (NIDDK) effectively oversees the national diabetes research effort without compromising creativity. Political lobbying in Congress in Washington and public advocacy throughout the country have resulted in increased funding for the NIDDK, with special appropriations amounting to some $\$ 1$ billion for diabetes research in the USA and indeed beyond, including Europe. The NIDDK knows how much is spent on diabetes research, in which specific area and by which investigators. There is no agency in Europe with such a detailed understanding of diabetes research in any single country, let alone the entire continent.

\section{DIAMAP: Road Map for Diabetes Research in Europe}

The Unit for Medical and Public Health Research at the Research Directorate of the European Commission understands this problem and shares the view that European diabetes research suffers from a lack of collective vision and coordination. Last year the Commission acted in an original and proactive way by inviting applications for the development of a road map of European diabetes research to be funded by a grant from the 7th Framework Programme (FP7). The Alliance for European Diabetes Research (EURADIA, http://www.euradia.org) applied and was awarded just over $€ 500,000$ for its project, Road Map for Diabetes Research in Europe (DIAMAP, grant number FP7 200701, http://www.diamap.eu). Work on this 2 year project started on 1 April 2008. 
The mission of DIAMAP is to identify overarching goals in all areas of diabetes research and propose a road map strategy for reaching these goals that will capitalise on European expertise.

A project steering committee of high-profile EURADIA members (representing patient organisations, academic science and industry) will provide scientific guidance for the project. The solid scientific backing of EURADIA and patient input provide credibility for DIAMAP to assimilate data on diabetes research currently being conducted in Europe. Diabetes research has been broken down into six major areas, each with its own group of experts chaired by an investigator with comprehensive scientific knowledge in the relevant focus area and more broadly in diabetes research. A seventh group will deal with horizontal themes that intersect the others, such as ethical and regulatory issues as well as training.

\section{DIAMAP: focused subgroups}

1. Genetics/Epidemiology Chair: N.J. Wareham, Cambridge, UK

2. Islets/Immunology Chair: T. Mandrup-Poulsen, Copenhagen, Denmark

3. Pathophysiology/Metabolism/Integrative physiology Chair: J.R. Zierath, Stockholm, Sweden

4. Clinical science and care

Chair: J.J. Nolan, Dublin, Ireland

5. Complications (microvascular)

Chair: P. Fioretto, Padua, Italy

6. Complications (macrovascular)

Chair: J. Skrha, Prague, Czech Republic

7. Horizontal issues (cross-cutting issues for research themes 1-6)

Chair: P.E. Schwarz, Dresden, Germany

The Chairs of the focused subgroups make up DIAMAP's Expert Advisory Board and will be driving the scientific aspects of the project.

Research road maps developed by each group will be compiled into a single report to provide the European Commission, private funding agencies, industry and researchers with a strategy to maximise the strengths and opportunities for future diabetes research in Europe. All stakeholders will participate through fora that will reinforce the intended focus on the patient.

\section{DIAMAP needs you!}

A second important and related mission of DIAMAP will be to undertake a wide survey of the current European diabetes research landscape, from which expert opinion can identify gaps and highlight strengths, to guide DIAMAP's road map strategy for diabetes research in Europe.

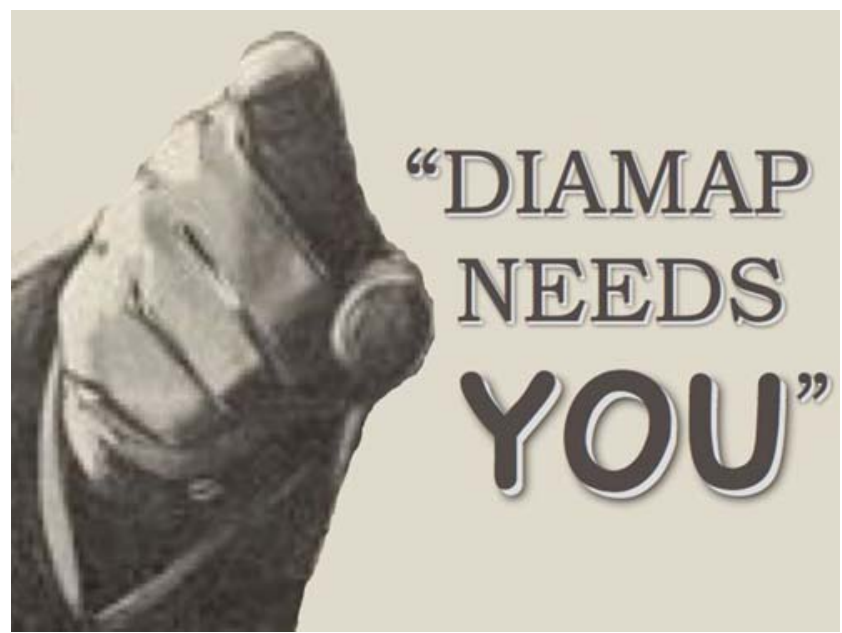

For this survey to be relevant and as complete as possible, DIAMAP urgently needs input from as many individuals as possible who are involved in any aspect of diabetes research in Europe, from molecules to cells, organs and living animals, from patients and clinical research to patient care and education, health economics and health policy. Everyone is concerned! DIAMAP needs you! Two questionnaires can be found on the DIAMAP website (http://www.diamap.eu). One relates to what research you do (Research Questionnaire) and the other to the source of funding (Funding Questionnaire). All independent investigators (group leaders) are asked to complete the Research Questionnaire, regardless of their background and profession. The Funding Questionnaire should be completed by organisations providing funding for diabetes research. DIAMAP needs this information! Without these data, DIAMAP will have no way of knowing who is doing what in diabetes research and where in Europe. We will not know who is paying for this research and how much is being 
spent. Moreover, this snapshot of the state of European diabetes research today will provide a point of departure for the road maps.

\section{You need DIAMAP!}

Without a massive response to these questionnaires, DIAMAP will not be able to deliver on its promise. We expect some of you to ask an obvious question followed by a few equally predictable statements: Why me? I hate these questionnaires and I am a very busy person. They can manage without me. Wrong: we cannot manage without you. This is a unique opportunity to make your voice heard in the European diabetes research arena. This is a way for you to ensure that your specific focus area is taken seriously and that it is on the research map when important decisions are taken about funding priorities. We often complain that our particular field of research is not well funded; now you can help change that! Others will answer the questionnaires and if you (and colleagues working in the same area as you) do not, the road maps may be distorted and your research field may end up being disadvantaged.
Putting our house in order: a model for others

A massive response will send a very strong signal to politicians, civil servants and all stakeholders (including private and public funding agencies as well as industry), that we are all part of the larger 'diabetes family', alongside patients and their families, and that we share the same concerns. We must work together to put our house in order for the benefit of all individuals with diabetes and for society at large. DIAMAP is unique. It is the first time anything of this kind has been attempted in any disease area in Europe. Diabetes is taking the lead where others will follow. However, this will only work if you, too, are fully involved.

Acknowledgements DIAMAP is supported by grant FP7 200701 from the European Commission and coordinated by EURADIA, a non-profit organisation registered in Germany.

\section{Duality of interest}

The authors declare that there is no duality of interest associated with this manuscript. The opinions expressed in this article are those of the authors and not necessarily those of the organisations they represent as elected officers. 